\title{
PENGARUH METODE PARTISIPATORI TERHADAP HASIL BELAJAR MATEMATIKA
}

\author{
M. Ardiansyah \\ Program Studi Teknik Informatika, Universitas Indraprasta PGRI \\ Email: m.ardiansyah_unindra@yahoo.co.id
}

\begin{abstract}
Abstrak
Kegunaan penelitian ini adalah sebagai bahan referensi untuk penelitan lanjutan dengan tema yang sama akan tetapi dengan metode, teknik analisa atau populasi dan sampel berbeda sehingga dapat dilakukan proses verifikasi demi kemajuan ilmu pengetahuan khususnya perbaikan kualitas pendidikan di Indonesia. Metode penelitian yang digunakan adalah Metode Eksperimen. Dengan jumlah sampel masing-masing kelompok sebanyak 20 orang yang diambil dengan menggunakan teknik purposive sampling. Instrumen yang digunakan adalah instrument test yang berbentuk pilihan ganda sebanyak 20 soal dan 5 alternatif jawaban. Uji persyaratan analisis data yang digunakan adalah uji normalitas menggunakan uji Lilliefors dan uji homogenitas menggunakan uji f (Fisher), dan hasilnya berdistribusi normal serta memenuhi uji homogenitas yakni data bersifat homogen sehingga analisa komparasi dapat dilanjutkan dengan statistik non parametric. Hasil uji hipotesis menunjukkan bahwa nilai $\mathrm{t}_{\text {hit }}=1,83$ dan nilai $\mathrm{t}_{\text {tab }}$ untuk $\alpha=0,05$ dan $\mathrm{d}_{\mathrm{k}}=38$ sebesar 1,68 yang berarti terdapat pengaruh metode partisipatori terhadap hasil belajar matematika.
\end{abstract}

Kata Kunci: Metode partisipatori, hasil belajar matematika

\section{Pendahuluan}

Dalam rangka meningkatkan mutu pendidikan, pembenahan secara terus menerus baik dari segi materi, metode maupun evaluasi harus dilaksanakan oleh semua pihak terutama seorang guru. Para ahli pendidikan menyatakan bahwa dalam proses belajar mengajar, guru seharusnya memiliki strategi yang tepat agar siswa dapat belajar secara efektif dan efisien sehingga tujuan pembelajaran dapat dicapai dengan optimal. Untuk menerapkan strategi yang tepat maka guru harus menguasai beragam metode mengajar. Hal ini sesuai dengan pendapat (Roestiyah, 2008) yang menyatakan bahwa seorang guru harus mengenal sifat-sifat yang khas pada setiap teknik penyajian, hal itu sangat perlu untuk penguasaan setiap teknik penyajian, agar ia mampu mengetahui, memahami dan terampil menggunakannya, sesuai dengan tujuan yang akan dicapai. Mengajar yang efektif sangat bergantung pada pemilihan metode dan strategi pembelajaran yang digunakan oleh guru dalam melaksanakan proses belajar di sekolah. Hal ini sangat bergantung terhadap pencapaian tujuan yang ingin dicapai dalam pembelajaran. Dengan menggunakan metode pengajaran yang tepat akan meningkatkan kemampuan siswa dalam memahami dan menguasai materi pelajaran sehingga pencapaian tujuan pengajaran dapat ditingkatkan.

Dalam proses pembelajaran matematika masih banyak siswa mengalami kesulitan dalam memahami konsep yang diajarkan. Kurangnya pemahaman konsep tersebut disebabkan oleh beberapa faktor antara lain metode pembelajaran yang digunakan dan karakteristik siswa. Metode pembelajaran yang digunakan lebih banyak menerapkan metode ekspositori dalam menyampaikan materi pelajaran, dimana siswa dipandang sebagai objek yang menerima apa yang diberikan oleh guru. Hal ini senada dengan pendapat (Sagala, 2012) mengatakan bahwa hakekat pengajaran ekspositori adalah menyampaikan ilmu pengetahuan kepada siswa, dimana siswa dipandang sebagai obyek yang menerima apa yang diberikan oleh guru. Dalam metode tersebut diharapkan dapat menangkap dan mengingat informasi yang telah diberikan guru. Komunikasi yang digunakan oleh guru adalah komunikasi satu arah, sehingga kegiatan belajar siswa kurang optimal sebab terbatas pada mendengarkan uraian guru dan mencatat. 
Pembelajaran seperti ini akan berdampak pada aktivitas siswa yang masih rendah, seperti kurangnya aktivitas siswa untuk bertanya dan menyampaikan pendapatnya. Hal ini berakibat pada rendahnya hasil belajar matematika siswa.

Berdasarkan informasi dari guru matematika SMK Widya Manggala Jakarta bahwa terdapat faktor dari dalam diri siswa yang mempengaruhi rendahnya hasil belajar antara lain siswa malu bertanya kepada guru walaupun ada materi yang belum dimengerti dan kemampuan awal siswa yang masih rendah serta sebagian besar siswa kurang menguasai pengetahuan yang merupakan prasyarat. Selain faktor tersebut terdapat faktor lain yaitu kemampuan siswa menggunakan apa yang dipelajari untuk menyelesaikan soal masih sebatas kemampuan menerapkan rumus di dalam penyelesaian soal persis seperti contoh yang diberikan guru, sehingga dalam menghadapi aplikasi soal siswa masih mengalami kesulitan.

Untuk memberikan kesempatan kepada siswa untuk belajar lebih aktif, lebih berpartisipasi serta mampu berinteraksi satu sama lain dalam pembelajaran diperlukan metode pembelajaran yang tepat. Salah satu metode pembelajaran yang dapat diterapkan adalah metode partisipatori. Metode partisipatori memberikan kesempatan kepada siswa dan guru secara bersama sama proaktif di dalam pembelajaran. Siswa tidak hanya menjadi objek dalam pembelajaran namun dapat menjadi subjek yang aktif dan kreatif. Siswa dapat bertukar pikiran dengan teman dan saling membantu dalam memahami konsep. Apabila terjadi kesulitan maka mereka akan dibantu oleh gurunya, karena guru berfungsi sebagai fasilitator dalam pembelajaran.

Sebagaimana ditegaskan oleh (Suyatno, 2004) metode pembelajaran yang mampu mengajak siswa terlibat secara penuh dalam kegiatan pembelajaran adalah metode partisipatori. Metode partisipatori adalah metode pembelajaran yang menekankan keterlibatan siswa secara penuh. Siswa dianggap sebagai penentu keberhasilan belajar. Pembelajaran partisipatori, disamping bermanfaat untuk mengaktifkan siswa dan membiasakan siswa mengerjakan tugas secara mandiri, juga dapat menimbulkan suasana belajar yang kondusif dikarenakan guru sebagai pembimbing dan teman belajar sehinggah dapat meningkatkan hasil belajar siswa.

Penelitian ini bertujuan untuk mengetahui pengaruh Metode Partisipatori terhadap hasil belajar matematika pada siswa kelas X SMK Widya Manggala Jakarta pokok bahasan Program Linier. Adapun manfaat dari penelitian ini adalah: 1) Bagi siswa: dengan pembelajaran partisipatori diharapkan anak menjadi aktif belajar dan dapat mengatasi kesulitan belajar yang sedang dihadapi sehingga hasil belajar mereka semakin meningkat. 2) Bagi guru: dapat dijadikan sebagai alternatif dalam mengembangkan pendekatan pembelajaran guna meningkatkan hasil belajar siswa dalam materi program linear. 3) Bagi sekolah: sebagai bahan pertimbangan penyusunan dan pelaksanaan program dalam belajar mengajar matematika di sekolah.

\section{Tinjauan Pustaka}

\section{Belajar}

Belajar sangat berperan aktif dalam perubahan tingkah laku seseorang, sesuai dengan tujuan yang ingin mereka capai. Tujuan tesebut yang mendorong seseorang untuk belajar agar dapat menguasai bidang yang ingin ia tekuni lebih dalam. Hal ini sesuai dengan pendapat (Hakim, 2005) bahwa "belajar adalah suatu proses perubahan di dalam kepribadian manusia, dan perubahan tersebut ditampakkan dalam bentuk peningkatan kualitas dan kuantitas tingkah laku seperti peningkatan kecakapan, pengetahuan, sikap, kebiasaan, pemahaman, keterampilan, daya pikir dan kemampuan lainnya". (Slameto, 2010) mengatakan "belajar adalah suatu proses usaha yang dilakukan seseorang untuk memperoleh suatu perubahan 
tingkah laku yang baru secara keseluruhan, sebagai hasil pengalamannya sendiri dalam interaksi dengan lingkungannya. Belajar merupakan suatu proses mencapai tujuan. Jadi, ada langkah-langkah atau prosedur yang harus ditepuh. Burton dalam (Hamalik, 2008) menyimpulkan uraian yang cukup panjang tentang prinsip-prinsip belajar mengenai proses belajar sebagai berikut:

1. Proses belajar ialah pengalaman, berbuat, mereaksi dan melampaui (under going).

2. Proses itu melalui bermacam-macam ragam pengalaman dan mata pelajaran-mata pelajaran yang terpusat pada suatu tujuan tertentu.

3. Pengalaman belajar secara maksimum bermakna bagi kehidupan murid.

4. Pengalaan belajar bersumber dari kebutuhan dan tujuan murid sendiri yang mendorong motivasi yang kontinu

5. Proses belajar dan hasil belajar disyarati oleh hereditas dan lingkungannya.

6. Proses belajar dan hasil usaha belajar secara materiil dipengaruhi oleh perbedaan-perbedaan individual di kalangan murid-murid.

7. Proses belajar berlangsung secara efektif apabila pengalaman-pengalaman dan hasil yang diinginkan disesuikan dengan kematangan murid.

8. Proses belajar yang baik apabila murid mengetahui status dan kemajuan.

9. Proses belajar merupakan kesatuan fungsional dari berbagai prosedur.

10. Proses belajar berlangsung secara efektif di bawah bimbingan yang merangsang dan membimbing tanpa tekanan dan paksaan.

Dari pendapat di atas, dapat disimpulkan bahwa seseorang akan mengalami perubahan apabila ia belajar dengan sebaik-baiknya dan belajar didapat dari sebuah pengalaman yang terjadi pada diri individu masing-masing serta dapat berkomunikasi dan berinteraksi dengan lingkungannya dengan baik.

\section{Hasil Belajar}

Hasil belajar merupakan kemampuan yang diperoleh seseorang setelah ia mengikuti atau mengalami proses belajar. Proses belajar yang terjadi pada diri seseorang akan menghasilkan perubahan tingkah laku. Perubahan ini dinamakan hasil belajar (learning outcomes). Peristiwa pembelajaran yang dilakukan pengajar bersama-sama dengan peserta didik dilakukan untuk mencapai tujuan pembelajaran. Hasil belajar adalah penampilan dan tingkah laku yang diperoleh peserta didik dari hasil pengorganisasian aktivitas pendidikan yang sengaja berkesinambungan sehingga muncul sikap yang lebih baik dari proses belajar yang dilakukan oleh peserta didik.

Menurut (Sappaile, 2006) "hasil belajar adalah suatu istilah yang digunakan untuk menunjuk sesuatu yang dicapai seseorang setelah melakukan suatu usaha. Bila dikaitkan dengan belajar berarti hasil menunjuk sesuatu yang dicapai oleh seseorang yang belajar dalam selang waktu tertentu". (Sudjana, 2004) mengemukakan "hasil belajar adalah kemampuan-kemampuan yang dimiliki mahasiswa setelah menerima pengalaman belajarnya". Dari definisi tersebut dapat disimpulkan bahwa hasil belajar adalah kemampuan yang dicapai oleh seseorang setelah seseorang melakukan kegiatan pembelajaran yang optimal. Sesuatu yang dicapai sebagai suatu hasil belajar didapat dalam jangka waktu tertentu. Hal ini dijabarkan oleh (Sukmandari, 2010) "hasil belajar adalah kemampuan yang dimiliki siswa setelah melalui pengalaman belajar. Hasil belajar ditandai dengan perubahan tingkah laku yang mencakup aspek kognitif, afektif, psikomotor".

Berdasarkan pernyataan yang telah diuraikan di atas, maka yang dimaksud dengan hasil belajar siswa dalam penelitian ini adalah kemampuan siswa berupa pengetahuan, sikap dan keterampilan setelah mengikuti proses pembelajaran, ditandai dengan perubahan tingkah laku yang mencakup aspek kognitif, afektif, psikomotor terwujud dalam bentuk nilai dalam pelajaran matematika. 


\section{Matematika}

Istilah matematika berasal dari bahasa Yunani "mathein" atau "manthein" yang artinya mempelajari. Menurut (Manfaat, 2010), matematika berasal dari kata mathema dalam bahasa Yunani yang diartikan sebagai sains, ilmu pengetahuan atau belajar, juga dari kata mathemathikos yang diartikan sebagai belajar. Sedangkan pendapat (Sanusi, 2009) "matematika merupakan ilmu universal yang mendasari perkembangan teknolgi modern, mempunyai peran penting dalam berbagai disiplin ilmu dan memajukan daya pikir manusia". (Paneo, 2007) memberikan banyak pengertian dari matematika sebagai berikut: 1) matematika adalah ilmu pengetahuan tentang struktur yang terorganisir, 2) matematika adalah ilmu deduktif, 3) Matematika adalah ilmu tentang pola dan hubungan , 4) matematika mencakup empat wawasan: aritmatika, aljabar, geometri, analisis, 5) matematika bahasa yang menggunakan istilah secara cermat, jelas, akurat, 6) matematika adalah ilmu tentang logika , 7) matematika adalah ilmu tentang bilangan dan ruang serta operasinya.

Dari pengertian di atas, maka dapat disimpulkan bahwa matematika adalah suatu pengetahuan yang eksak dan terorganisir secara sistematik yang mempelajari objek-objek berupa fakta, konsep, operasi, dan prinsip yang semuanya adalah abstrak.

\section{Hasil Belajar Matematika}

Sukmandari $(2010,69)$ menyatakan hasil belajar matematika adalah "suatu kegiatan yang dilakukan siswa dalam mempelajari matematika untuk menghasilkan perubahan tingkah laku yang berhubungan dengan aspek kognitif, afektif, dan psikomotor yang berlangsung cukup lama". (Darmiyati, 2007) "hasil belajar matematika adalah penguasaan siswa terhadap materi pelajaran, sebelumnya memperoleh pengalaman belajar yang diperlihatkan siswa melalui nilai tes yang diberikan guru". Hal tersebut juga didukung oleh pernyataan (Mutakin, 2011), "hasil belajar matematika adalah pengetahuan yang dimiliki atau diperoleh siswa dari belajar matematika yang meliputi pengertian, pemahaman, penguasaan akan konsep perhitungan serta pemecahan problema matematika".

Berdasarkan pengetahuan di atas, maka dapat disimpulkan bahwa hasil belajar matematika adalah merupakan hasil belajar yang dicapai oleh seseorang setelah mengalami proses belajar matematika yang dilakukan secara sadar dan diwujudkan dalam bentuk perubahanperubahan sikap, tingkah laku, dan keterampilan menggunakan matematika dalam kehidupan sehari-hari.

\section{Metode Pembelajaran}

Metode berasal dari bahasa latin "Methods" yang artinya jalan yang harus dilalui, dengan kata lain metode adalah cara untuk mencapai suatu tujuan. Dari pengertian ini, metode adalah alat yang dipergunakan untuk mencapai tujuan, maka diperlukan pengetahuan tentang tujuan itu sendiri. Hal ini sesuai dengan pendapat (Sholeh, 2011), metode adalah jalan yang harus dilalui untuk mencapai tujuan. Pembelajaran diartikan sebagai proses interaksi peserta didik dengan pendidik dan sumber belajar pada suatu lingkungan belajar. Pembelajaran yang dimaksud adalah bantuan yang diberikan oleh pendidik agar terjadi proses perolehan ilmu dan pengetahuan, penguasaan kemahiran dan tabiat, serta pembentukan sikap dan kepercayaan kepada peserta didik. Sedangkan (Sagala, 2012) menyatakan bahwa pembelajaran adalah kegiatan guru secara terprogram dalam desain instruksional, untuk membuat siswa belajar secara aktif, yang menekankan pada penyediaan sumber belajar. Syah $(2010,201)$ metode mengajar adalah cara yang berisi prosedur baku untuk melaksanakan kegiatan kependidikan khususnya kegiatan penyajian kepada siswa. Guru dalam menerapkan metode pembelajaran terlebih dahulu melihat situasi dan kondisi yang paling tepat untuk dapat diterapkannya suatu metode tertentu agar dalam situasi dan kondisi tersebut membawa siswa ke arah yang sesuai dengan materi yang ingin diajarkan. 
Dari uraian teori di atas dapat diambil suatu kesimpulan bahwa metode pembelajaran adalah suatu pola-pola umum kegiatan yang merupakan interaksi guru dengan peserta didik atau cara yang dilakukan oleh pendidik dalam menyampaikan, memilih, dan mengidentifikasikan dan mencerna pembelajaran demi mencapai tujuan pembelajaran.

\section{Metode Pembelajaran Partisipatori}

Menurut (Ahmadi, dkk, 2011), metode pembelajaran partisipatori merupakan model pembelajaran dengan melibatkan peserta didik secara aktif dalam perencanaan, pelaksanaan dan evaluasi pembelajaran.Hal ini juga senada dengan pendapat (Suyatno, 2004) yang mengemukakan bahwa metode partisipatori adalah metode pembelajaran yang menekankan keterlibatan siswa secara penuh dalam proses belajar mengajar, siswa dianggap sebagai penentu keberhasilan belajar yang diduduki sebagai subjek belajar sedangkan guru hanya sebagai pemandu atau fasilitator. (Agung, 2012) menyatakan bahwa metode partisipatori adalah upaya untuk melibatkan partisipasi baik itu pihak-pihak yang berada di lingkungan organisasi itu maupun pihak yang berada di luar organisasi. (Pidarta, 2005) mengemukakan partisipatori berasal dari kata partisipasi yaitu perlibatan seseorang atau beberapa orang dalam suatu kegiatan, yang dalam hal ini adalah kegiatan pembelajaran".

Metode partisipatori mempunyai 3 ciri utama, yaitu belajar dari realitas atau pengalaman, tidak menggurui dan dialogis. Metode partisipatori menggunakan pendekatan proses dengan menerapkan pola induktif. Pengajaran dengan pola induktif dimulai dengan memberikan bermacam-macam contoh, dari contoh tersebut siswa mengerti keteraturan dan kemudian mengambil keputusan/kesimpulan yang bersifat umum (Memes, 2009). Tahapan-tahapan dalam pembelajaran dengan pola induktif antara lain: persepsi, identifikasi, aplikasi, penguatan, pengukuhan, dan refleksi. Jadi, dari definisi tersebut dapat disimpulkan bahwa pada metode partisipatori merupakan suatu metode yang dipergunakan oleh pendidik di mana pendidik hanya menjadi fasilitator pendukung tujuan pembelajaran, dan peserta didik adalah objek utama dalam menciptakan tujuan pembelajaran. Karakteristik dalam metode partisipatori sangat diperlukan guna memperoleh komunikasi yang baik antara pendidik dan peserta didik.

\section{Metodologi Penelitian}

Metode penelitian yang digunakan adalah metode eksperimen, yaitu dengan memberikan jenis perlakuan yang berbeda pada dua kelompok belajar siswa. Hasil belajar yang merupakan data dari penelitian itu dikelompokkan menjadi hasil belajar kelas eksperimen dan hasil belajar kelas kontrol. Manipulasi variabel dalam penelitian ini dilakukan pada variabel bebas yaitu pembelajaran matematika dengan metode Partisipatori pada kelas eksperimen dan pembelajaran ekspositori pada kelas kontrol.

Sebelum diberi perlakuan, terlebih dahulu akan dilihat kemampuan awal dari sampel penelitian yang akan dikenai perlakuan, baik dari kelompok eksperimen maupun kontrol. Pada kelompok eksperimen diberikan perlakuan khusus yaitu pada pembelajaran matematika dengan metode partisipatori, sedangkan pada kelompok kontrol diberikan pembelajaran matematika dengan metode ekspositori. Pada akhir eksperimen kedua kelompok tersebut diukur dengan menggunakan alat ukur yang sama, yaitu tes hasil belajar matematika. Hasil pengukuran tersebut diukur kemudian dianalisa dan dibandingkan dengan tabel uji statistik yang digunakan.

Tabel 1. Desain Penelitian 


\begin{tabular}{|l}
$\mathrm{Y}_{1} \longrightarrow \mathrm{X}_{\mathrm{E}} \longrightarrow \mathrm{Y}_{2}$ \\
\hline $\mathrm{Y}_{1} \longrightarrow \mathrm{X}_{\mathrm{K}} \longrightarrow \mathrm{Y}_{2}$ \\
\hline
\end{tabular}

Keterangan :

E : Kelompok eksperimen (penggunaan metode partisipatori)

$\mathrm{K}$ : Kelompok kontrol (penggunaan metode ekspositori)

$\mathrm{X}_{\mathrm{E}} \quad$ : Perlakuan terhadap kelompok eksperimen

$\mathrm{X}_{\mathrm{K}} \quad$ : Perlakuan terhadap kelompok kontrol

$\mathrm{Y}_{1} \quad$ : Tes awal

$\mathrm{Y}_{2} \quad$ : Tes akhir

\section{Hasil dan Pembahasan}

Data hasil belajar matematika dengan metode partisipatori

Setelah tes diberikan kepada kelas eksperimen yang di dalam proses pembelajarannya diberikan pengajaran dengan menggunakan metode partisipatori dengan jumlah siswa sebanyak 20 siswa, maka diperoleh nilai berkisar antara 52 sampai 96. Nilai rata-rata 78,50; median 81,50; modus 83,41; Varian 160,66; dan simpangan baku sebesar 11,86. Dengan demikian dapat dikatakan bahwa hasil belajar matematika siswa yang diajarkan dengan metode partisipatori sedang dan tidak banyak beragam.

Data hasil belajar matematika dengan metode ekspositori

Setelah tes diberikan kepada kelas kontrol yang di dalam proses pembelajarannya diberikan pengajaran dengan menggunakan metode ekspositori dengan jumlah siswa sebanyak 20 siswa, maka diperoleh nilai berkisar antara 44 sampai dengan 96. Dengan nilai rata-rata 70,95; median 70,50; modus 83,10; Varian 200,16; dan simpangan baku sebesar 14,15. Dengan demikian dapat dikatakan bahwa hasil belajar matematika siswa yang diajarkan dengan metode ekspositori sedang dan tidak banyak beragam.

\section{Pengujian persyaratan analisis data}

Untuk mengetahui pengaruh metode partisipatori terhadap hasil belajar matematika, dalam penelitian ini dilakukan uji normalitas yang diberikan kepada kedua kelompok kelas yang diberikan perlakuan berbeda dan diharapkan data yang di peroleh dari hasil penelitian berdistribusi normal. Untuk menguji kenormalan hasil penelitian digunakan uji Lilliefors. Dalam perhitungan diperoleh Lo dengan $n=20$ pada taraf signifikan $\alpha=0,05$. karena Lo < $\mathrm{L}_{\text {tabel }}$ yaitu $0,1228<0,190$ maka $\mathrm{H}_{0}$ diterima. Dapat disimpulkan bahwa data hasil belajar matematika siswa kelas eksperimen berasal dari sampel yang berdistribusi normal.

Kemudian kedua sampel tersebut dilakukan pengujian kesamaan dua varians (uji homogenitas) untuk mengetahui apakah data kedua kelompok homogen. Dari hasil perhitungan didapat $F_{\text {hit }}=1,423<2,165$ atau $F_{\text {hit }}<F_{\text {tabel }}$ sehingga $H_{0}$ diterima pada taraf nyata $\alpha=0,05$. Oleh karena itu, maka dapat disimpulkan bahwa dua sampel tersebut mempunyai varians yang sama (homogen) setelah diberi perlakuan.

Pengujian penelitian ini diuji melalui uji hipotesis (uji-t) dan dalam perhitungan didapat $t_{\text {hitung }}>t_{\text {tabel }}(1,83>1,68)$ maka $\mathrm{H}_{0}$ ditolak dan $\mathrm{H}_{1}$ diterima pada $\alpha=0,05$. Dengan demikian rata-rata hasil belajar matematika siswa yang diajarkan dengan metode partisipatori lebih tinggi dari rata-rata hasil belajar matematika yang diajarkan dengan metode ekspositori. Atau dapat disimpulkan terdapat pengaruh metode partisipatori terhadap hasil belajar matematika siswa.

\section{Pembahasan}

Dari hasil perhitungan diperoleh data rata-rata hasil belajar matematika dengan menggunakan metode partisipatori sebesar 78,50 sedangkan rata-rata hasil belajar 
matematika dengan menggunakan metode ekspositori sebesar 70,95. Dari hasil perhitungan dapat di lihat bahwa rata-rata hasil belajar matematika siswa yang menggunakan metode partisipatori lebih tinggi dibandingkan dengan rata-rata hasil belajar matematika siswa yang menggunakan metode ekspositori. Dengan demikian berarti perbedaan hasil belajar matematika bukan secara kebetulan, melainkan karena perbedaaan perlakuan antara dua kelompok tersebut.

Dari hasil pengujian hipotesis statistik data diperoleh nilai $t_{\text {hitung }}=1,83$ dan $t_{\text {tabel }}=1,68$ pada taraf signifikan $\alpha=5 \%$ yang berarti nilai $t_{\text {hitung }}>t_{\text {tabel }}(1,83>1,68)$. Hasil tersebut menunjukkan bahwa $\mathrm{H}_{0}$ ditolak dan $\mathrm{H}_{1}$ di terima, dengan diterimanya $\mathrm{H}_{1}$ hal ini berarti telah membuktikan kebenaran dari hipotesis. Dengan demikian pemberian pembelajaran dengan menggunakan metode partisipatori berpengaruh terhadap hasil belajar matematika. Sehingga dapat disimpulkan bahwa pemberian pembelajaran dengan menggunakan metode partisipatori berpengaruh positif terhadap hasil belajar matematika.

Melalui pembelajaran dengan menggunakan metode partisipatori siswa dapat lebih berperan aktif dan dapat mengingat serta mengkreasikan pengetahuan yang telah dipelajarinya dalam kehidupan sehari-hari. Matematika yang abstrak dan sukar dapat dikurangi. Dengan menerapkan konsep pembelajaran dengan menggunakan metode partisipatori siswa dapat mengerjakan tugas yang telah diberikan dan dapat mentransferkan pengetahuannya serta bertukar pikiran dengan siswa lain. Pembelajaran dengan menggunakan metode partisipatori juga memberi kesempatan siswa untuk dapat mengembangkan pengetahuan yang mereka miliki dan berani dalam memberikan pendapat dan mengomentari hal-hal yang menurutnya perlu untuk di koreksi.

Pembelajaran yang dilaksanakan pada kelas kontrol yaitu pembelajaran dengan menggunakan metode ekspositori belum dapat memotivasi siswa untuk dapat meningkatkan aktivitas dalam pembelajaran. Pembelajaran pada kelas kontrol memang dapat membuat siswa lebih tenang karena guru yang memegang kendali kelas. Siswa hanya duduk dan memperhatikan penjelasan guru, akan tetapi pemahaman siswa tentang materi yang telah disampaikan kurang maksimal. Siswa yang belum paham kadang-kadang takut dan malu untuk bertanya pada guru. Hal ini mengakibatkan siswa yang kurang paham tentang materi yang diajarkan oleh guru, kemampuannya tidak bisa meningkat dan tidak merata.

Secara keseluruhan hasil dari penelitian ini menunjukkan bahwa penerapan metode partisipatori dapat meningkatkan hasil belajar siswa. Hal ini disebabkan karena dalam penerapan metode partisipatori siswa sendiri belajar melalui partisipasi secara aktif untuk menemukan suatu konsep atau prinsip, dari pengalaman yang mereka miliki. Hal ini menuntut siswa berpikir dan menggunakan segala kemampuannya sehinggga siswa merasakan pembelajaran yang bermakna untuk dirinya sendiri.

Berdasarkan pembahasan di atas, pembelajaran dengan menggunakan metode partisipatori dapat meningkatkan hasil belajar siswa. Hal ini dikarenakan karena pembelajaran dengan menggunakan metode partisipatori dapat mempermudah siswa dalam memahami pelajaran matematika, sehingga siswa menganggap bahwa matematika itu adalah pelajaran yang tidak sulit untuk dipelajari.

\section{Simpulan dan Saran}

\section{Simpulan}


Berdasarkan hasil pengujian hipotesis yang menunjukkan $t_{\text {hitung }}$ lebih besar dari $t_{\text {tabel }}$ yaitu $t_{\text {hitung }} 1,83$ dan $t_{\text {tabel }}=1,68$ sehingga didapat $t_{\text {hit }}>t_{\text {tabel }}(1,83>1,68)$. Kesimpulan $H_{0}$ ditolak yang berarti hasil belajar matematika yang diajarkan dengan metode partisipatori lebih tinggi dari pada hasil belajar matematika yang diajarkan dengan metode ekspositori. Hal ini berarti bahwa pemberian perlakuan yang berbeda memberikan perubahan dan pengaruh yang signifikan pada pada hasil belajar matematika siswa di SMK Widya Manggala Jakarta.

\section{Saran}

Berdasarkan hasil penelitian ini maka saran dan harapan yang bisa peneliti sampaikan adalah:

1. Bagi Mahasiswa/pihak yang ingin meneliti lebih lanjut mengenai pembelajaran dengan metode partisipatori untuk mencoba menerapkan pada pokok bahasan lain dan lebih sempurna dari penelitian ini.

2. Bagi Guru Matematika, penelitian ini dapat menjadi pedoman bagi perkembangan pembelajaran metode partisipatori pada siswa lainnya dan menerapkannya pada pembelajaran di kelas dengan materi yang berbeda.

3. Guru dapat lebih mengembangkan kreativitas dalam mengajar sebagai upaya mewujudkan pembelajaran yang berpusat pada siswa dalam sistem mangajar sehingga berpengaruh pada hasil belajar matematika siswa

\section{Daftar Pustaka}

Agung, Iskandar. (2012). Strategi Mengembangkan Organisasi Pembelajar di Sekolah. Jakarta: Bee Media Indonesia.

Ahmadi, dkk. (2011). Strategi Pembelajaran Berorientasi KTSP. Jakarta: PT Prestasi Pustakaraya.

Alwi, H. (2005). Kamus Besar Bahasa Indonesia. Jakarta: Balai Pustaka.

Darmiyati. (2007). Implementasi Asesmen Diagnostik dalam Upaya Meningkatkan Hasil Belajar Matematika di SD Kota Banjarbaru Kalimantan Selatan. Jurnal Pendidikan dan Kebudayaan. Vol. 13, No. 67, 509-531. Departemen Penelitian dan Pengembangan Departemen Pendidikan Nasional, Jakarta.

Manfaat, Budi. (2010). Membumikan Matematika dari Kampung ke Kampung. Jakarta: Buku kita.

Memes, Wayan. (2009). Model Pembelajaran Fisika di SMP. Jakarta: Proyek Pengembangan Guru Sekolah Menengah.

Mutakin, T. Z dan Sumiati, T. (2011). Pengaruh Penggunaan Media Belajar dan Minat Belajar terhadap Hasil Belajar Matematika. Jurnal Formatif. 1(1). 70-81. Fakultas Teknik, Matematika, dan Ilmu Pengetahuan Alam dan Lembaga Penelitian dan Pengabdian Masyarakat, UNINDRA PGRI.

Paneo, H. (2007). Pengaruh Umpan Balik Evaluasi Formatif dan Kepribadian Siswa terhadap Hasil Belajar Matematika. Jurnal Pendidikan dan Kebudayaan. Vol. 13, No. 67, 719-754. Departemen Penelitian dan Pengembangan Departemen Pendidikan Nasional, Jakarta.

Pidarta, Made. (2005). Perencanaan Pendidikan Partisipatori dengan Pendekatan Sistem. Jakarta: Rineka Cipta.

Roestiyah. (2008). Strategi Belajar Mengajar Cetakan ke Tujuh. Jakarta: PT Rineka Cipta.

Sagala, Syaiful. (2012). Konsep dan Makna Pembelajaran Cetakan ke Sepuluh. Bandung: Alfabeta. 
Sanusi, F.P.I. (2009). Upaya Meningkatkan Hasil Belajar Matematika Operasi Hitung Bilangan Bulat melalui Penggunaan Alat Peraga Mistar Hitung bagi Siswa Kelas 7A SMP Maria Mediatrix pada Semester Gasal Tahun 2008/2009. Bhakti Utama: Majalah/Jurnal Pendidikan. Vol. 2, No. 3, 102-107. Yayasan Bhakti Karya, Surabaya.

Sappaile, B.I. (2006). Pengaruh Metode Mengajar dan Ragam Tes terhadap Hasil Belajar Matematika dengan Mengontrol Sikap Siswa. Jurnal Pendidikan dan Kebudayaan. Edisi Khusus. 1-23.Departemen Penelitian dan Pengembangan Departemen Pendidikan Nasional, Jakarta.

Sholeh, Hamid. (2011). Metode Edutainment. Yogyakarta: Diva press.

Slameto. (2010). Belajar dan Faktor-faktor yang Mempengaruhinya. Jakarta: Rineka Cipta.

Sudjana, Nana. (2004). Penilaian Hasil Belajar Mengajar. Bandung: PT. Remaja Rosda Karya.

Sukmandari. (2010). Strategi Pembelajaran Snow Balling sebagai Upaya untuk Meningkatkan Aktivitas dan Hasil Belajar Matematika Tentang Barisan dan Deret Bagi Siswa Kelas 9 D SMP N 1 Mlonggo Semester 2 Tahun 2009/2010. Adi Cendikia: Jurnal Pendidik dan Tenaga Kependidikan. Vol. 3, No. 3, 67-73. Yayasan Bina Insan Mandiri.

Surya, Muhammad. (2004). Psikologi Pembelajaran dan Pengajaran. Bandung: Pustaka Bani Quraisy.

Suyatno. (2004). Teknik Pembelajaran Bahasa dan Sastra. Surabaya: SIC.

Syah, Muhibbin. (2010). Psikologi Pendidikan dengan Pendekatan Baru. Bandung: Remaja Rosdakarya 